\title{
Paula Milczarczyk \\ Artyfikacja codzienności i odwrócony mimetyzm, czyli życie, które naśladuje sztukę
}

\begin{abstract}
Milczarczyk Paula, Artyfikacja codzienności i odwrócony mimetyzm, czyli życie, które naśladuje sztukę [Artification of everday life and reversed mimetism or life that imitates art]. „Przestrzenie Teorii" 13. Poznań 2019, Adam Mickiewicz University Press, pp. 247-260. ISSN 1644-6763. DOI 10.14746/pt.2019.31.13.

In this paper, I analyse the phenomenon of artification of everyday experience. Using the concept of "artification" developed in the field of Everyday Aesthetics, I define the non-artistic experience, which is co-shaped by art and related to its models of perception. As the consequence of this mechanism, I indicate the tendency to project some artistic cognitive schemas (or their elements) to the existing reality. As a result of this process, events and non-artistic views are captured in the image of art, as "art-like". The process of the interpenetration of the fields of art and non-art may lead in turn to the reversal of the mimetic order - when artistic creation determines the forms of examining the world to the extent that it creates the effect of "life imitating art". This phenomenon of formalizing experience according to artistic models is illustrated by examples from the linguistics, visual arts and literature.
\end{abstract}

KEYWORDS: everyday aesthetics, artification, anti-mimetism, life imitating art

Historia twórczości awangardowej i poawangardowej dowodzi, że sztuka nie ma żadnych granic. Artystyczna „straż przednia” XX wieku, dążąca do zakwestionowania opozycji i zatarcia granic między twórczością a życiem, zapoczatkowała proces tak zwanej ontologizacji sztuki, czyli ontologicznego rozciagnięcia i ugruntowania w rzeczywistości pozaartystycznej - szczególnego rodzaju uwikłania sztuki w byt, w codzienność ${ }^{1}$. To wciąnięcie w pole kreacji elementów świata zastanego doskonale ilustruje zjawisko pop-artu (np. Brillo Boxes Andy'ego Warhola), tak zwanej sztuki biednej (tworzonej z „odpadków” codzienności, takich jak śmieci czy resztki organiczne), czy akcje typu performance. Najpełniejsza jednak ilustrację dla tej metody twórczej stanowić będzie z pewnościa sztuka gotowa (ready-made) ugruntowana jedynie $\mathrm{w}$ artystycznym geście przenoszącym przedmioty z jednej sfery (rzeczywistości pozaartystycznej) do drugiej (świata sztuki), w wyniku czego następuje zmiana statusu przedmiotu z „przypadkowego"

${ }^{1}$ T. Pękala, Awangarda i ariergarda. Filozofia sztuki nowoczesnej, Lublin 2000, s. 354. Zob. również podrozdział „Nowe doświadczenie estetyczne”, tamże, s. 353-358. 
w arcydzieło (tak zwana „transfiguracja” według określenia Artura Danto)². Duchampowski twórczy akt „wskazania”, który sprowadził zasadę mimesis do granic absurdu, ukazujacc, iż gest naśladownictwa może zostać sprowadzony do prostego przesunięcia znaczeń - rozsadził pojęcie sztuki od środka i zmienił jej oblicze na zawsze. Odtąd, nie tylko decyzją artysty (wspartego przez wykładnię teoretyczna), sztuką może stać się wszystko - od zdarzeń ujmowanych w struktury teatru (happening), przez przypadkowe dźwięki ulicy, które, zapisywane, zyskuja status dzieła muzycznego (tak zwane field recordings), po sterty odpadków organicznych eksponowane w galerii rzeźby (arte povera). W wyniku tego procesu elementy świata zastanego siła rzeczy przywołują skojarzenia z twórczością artystyczna, zyskują charakter sztukopodobny. Skutkiem ubocznym ontologizacji jest bowiem odwrócenie porządków, paradoksalny efekt, „życia naśladującego sztukę”, gdy mozaika suszącego się prania przywołuje skojarzenia z malarstwem abstrakcyjnym, zużyta tablica ogłoszeniowa przypomina instalację, a ustawione w równym rządku skompresowane kartony na tyłach hipermarketu - monumentalną rzeźbę. Ontologizacja gestu artystycznego z konieczności pociągnęła za sobą artyfikację świata zastanego. Odtąd, parafrazując jednego z głównych teoretyków awangardy, Arthura C. Danto, różnica między sztuką a rzeczywistością stała się w mniejszym stopniu różnicą dotyczącą rodzajów rzeczy niż rodzajów nastawienia, i w związku z tym, warto powtórzyć jeszcze raz słynne Dantowskie pytanie: ,[...] czy cały świat składa się z utajonych dzieł sztuki oczekujących, jak chleb i wino rzeczywistości, przemienienia [...] w nieodróżnialne ciało i krew”... sztuki? ${ }^{3}$.

\title{
Estetyka codzienności i artyfikacja
}

\begin{abstract}
Dostrzegamy na łagodnym śródziemnomorskim wzgórzu San Simeon zamek Williama Randolpha Hearsta. [...] Doszedtszy do szczytu bogactwa $i$ sławy, Hearst zbudowat sobie własna Fortece Samotności [...].

Niczym w filmie René Claira (ale w tym przypadku rzeczywistość znacznie przewyższa fikcje) kupit po kawatku albo w całości europejskie pałace, opactwa, klasztory, kazat je zdemontować i ponumerować cegła po cegle, następnie zaś wystać za ocean i odbudować ponownie na zaczarowanym wzgórzu, pośród dzikich zwierzat żyjacych na wolności

U. Eco Semiologia życia codziennego
\end{abstract}

${ }^{2}$ A.C. Danto, Świat sztuki. Pisma z filozofii sztuki, przeł. L. Sosnowski, Kraków 2006, s. 43. Znamienne są tu już same określenia, za pomocą których opisuje się ten typ działania artystycznego: ang. ready-made art (sztuka „gotowa”, ,już-zrobiona”) oraz fr. objet trouvé (przedmiot-sztuka „znaleziona”).

${ }^{3}$ Tamże. 
Spuścizna awangardy odcisnęła trwałe piętno nie tylko na sztuce, lecz również - w związku ze swoimi metodologicznymi założeniami i materią działań - na tym, w jaki sposób doświadczamy pozaartystyczną sferę życia. Ów szczególnego rodzaju panartyzm, który przyświecał twórczości awangardystów oraz ich następców, opierających swoje działania na przekonaniu, że wszystko w zastanym świecie nosi potencjał artystyczny, sprawił, że codzienność ukazała się w zupełnie nowym świetle. Świat stał się odtąd nieskończonym zbiorem potencjalnych dzieł sztuki i zarazem nowo odkrytym źródłem przeżyć o charakterze estetycznym, bliskim doświadczeniu artystycznemu.

Analizując pozaartystyczne sfery życia w wymiarze estetycznym, warto odwołać się do ustaleń wypracowanych na gruncie tak zwanej estetyki codzienności (Everyday Aesthetics) - jednego z najnowszych i dynamicznie rozwijających się nurtów filozoficznych. Dyskurs, skoncentrowany przede wszystkim wokół postulatu odwrotu od ujęć stawiających sztukę w centrum rozważań (estetyka jako filozofia sztuki), w swych założeniach kontynuuje jednocześnie Deweyowską tradycję estetyczną skupioną wokół nowej formy uczestnictwa w doświadczeniu. Reprezentanci nurtu, skłaniając się ku integralnemu przeżyciu, zrywają z Kantowskimi kategoriami bezinteresowności i dystansu, podkreślając jednocześnie wagę czynnego zaangażowania różnorodnych władz podmiotowych w doświadczenie: emocji, wiedzy, pamięci. Przeformułowanie samej kategorii „estetyczości” (oparte na powrocie do źródłowego aesthesis) prowadzi z kolei do powiększenia zakresu stosowalności tego pojęcia o przejawy tego, co potoczne i codzienne, a więc o wszelką praktykę życia. Zerwanie z perspektywą sztukocentryczną skutkuje tu bowiem szerokim ujęciem kategorii związanych zarówno ze sfera przedmiotu, jak i doświadczenia estetycznego: dzieło artysty okazuje się tylko szczególnym przypadkiem tego rodzaju przedmiotu, a samo doświadczenie estetyczne, rozumiane szeroko, nie musi wchodzić w relację z doświadczeniem sztuki. Aesthesis, uwolnione od naleciałości artystycznych, uniezależnia się od pola związanego z twórczą kreacją i odzyskuje swoją autonomię. W związku z tym zasadne staje się rozróżnienie na „czyste” doświadczenie estetyczne o charakterze pozaartystycznym oraz doświadczenie sztuki (lub takie, które uwikłane jest w kategorie z nią związane).

Warto zauważyć, że w ramach nurtu funkcjonują również dwa swoiste odłamy, które w sposób diametralnie różny ustosunkowują się do relacji sztuka-codzienność. Stanowisko reprezentowane przez Thomasa Leddy'ego ${ }^{4}$ charakteryzuje pozytywny stosunek do takiego typu doświadcze-

${ }^{4}$ Th. Leddy, The Extraordinary in the Ordinary: The Aesthetics of Everyday Life, Peterborough 2012. 
nia codzienności, które uwikłane jest w kategorie artystyczne (patrzenie na świat przez pryzmat sztuki). Z drugiej strony, w opozycji do podejścia Leddy'ego występuje, między innymi, Yuriko Saito ${ }^{5}$, która deprecjonuje ten rodzaj doświadczenia, postulując jednocześnie ujęcie codzienności „samej w sobie", a więc jako przedmiotu estetycznego o charakterze swoistym (niezależnym od sztuki). „[...] sztuka pomaga nam podchodzić do życia na sposób estetyczny, czyniąc nasze życie bogatszym" - zauważa filozofka, po czym jednak dodaje, że pod względem estetycznym nasza codzienność jest jeszcze bogatsza i bardziej zróżnicowana i, w związku z tym, podejścia zorientowane sztukocentrycznie okazują się dziś niewystarczające ${ }^{6}$. Według Saito aplikowanie modelu doświadczenia artystycznego do obszarów zwiazanych z codziennościa jest bowiem „nieadekwatne" i „mylace”" W opozycji do tego stanowiska Thomas Leddy podkreśla z kolei bliska relację, jaka łączy te dwie sfery, zauważając, że „dialektyka sztuki i codzienności czyni każde z nich znaczącym: stąd też, estetyka życia codziennego nie powinna dystansować się od estetyki sztuki". Według autora nie jesteśmy w stanie stworzyć pełnego obrazu żadnej z tych płaszczyzn bez uwzględnienia tej specyficznej, dialektycznej relacji. Nie uchwycimy pełni znaczenia sztuki bez zrozumienia, jak bardzo twórczość ugruntowana jest w codzienności, zaś codzienność umyka nam, gdy nie pojmiemy jej głębokiego związku ze sztuka.

$\mathrm{W}$ analizie relacji, jaka łączy artyzm i pozaartystyczne sfery życia, użyteczną kategorię stanowi również wypracowane na gruncie Everyday Aesthetics pojęcie tak zwanej artyfikacji (artification). Jak tłumaczy Ossi Naukkarinen: „artyfikacja odnosi się do sytuacji i procesów, w których coś, co nie jest traktowane jako sztuka w tradycyjnym sensie tego słowa, zmienia się w coś sztuko-podobnego [art-like] lub też w coś, co czerpie wpływy z artystycznych sposobów myślenia i działania. Odnosi się to do procesów, gdzie sztuka zostaje wymieszana z czymś innym, co przyswaja sobie pewne właściwości sztuki”" . Artyfikacja prowadzi więc do przemieszania dwóch przeciwstawnych porządków (artystycznego i nie-artystycznego), w wyniku czego sfery życia poza kreacją zyskują konotacje quasi-artystyczne (znamiona sztuki). Co istotne, mechanizm ten nie prowadzi jednak do zmiany statusu przedmiotów (zdarzeń, procesów itd.) z pozaartystycznych na artystyczne. Dychotomia sztuka/nie-sztuka musi zostać zachowana, by pozostała w mocy definiująca pojęcie artyfikacji zasada odniesienia: ,artyfikacja

${ }^{5}$ Y. Saito, Everyday Aesthetics, New York 2007.

${ }^{6}$ Tamże, s. 40. Wszystkie cytaty z pozycji anglojęzycznych podaję w tłumaczeniu własnym.

${ }^{7}$ Tamże, s. 41.

${ }^{8}$ Th. Leddy, dz. cyt., s. 112.

${ }^{9}$ O. Naukkarinen, Variations in Artification, „Contemporary Aesthetics”, Special Issue 2012,4 . 
nie może mieć miejsca bez sztuki; potrzebuje jej jako punktu odniesienia oraz źródła pomysłów i praktyk. Potrzebuje również rzeczy, które nie są sztuka, by jedne z drugimi mogły zostać zmieszane i oddziaływać na siebie nawzajem" - zaznacza Naukkarinen ${ }^{10}$. Fiński estetyk, podkreślając, że opisywany mechanizm odnosi się ściśle do współczesności (contemporary artification), skupia się w swoich analizach na takich sferach życia codziennego jak biznes, edukacja czy sport ${ }^{11}$. Czy jednak samo doświadczenie może zostać poddane artyfikacji tak, by, odnosząc się do pozaartystycznej sfery rzeczywistości, przypominało doświadczenie sztuki? Czym byłaby w takim przypadku „zartyfikowana codziennośé”?

Jak się wydaje, dzieła artystyczne (plastyczne, literackie, filmowe i inne) poprzez swą dialektyczną relację z rzeczywistością zastaną (Leddy), istotnie, mogą uczestniczyć w procesie artyfikacji samego doświadczenia codzienności. Jak wskazuje autor The Extraordinary..., prosta, codzienna czynność zakotwiczona w medium, jakim jest sztuka, może nabierać cech złożoności i zyskiwać tym samym zupełnie nową postać: „poezja na temat brania kapieli może zwracać uwagę na różnorodne jakości estetyczne, które towarzyszą tej czynności, i, co więcej, może również unifikować te jakości w jedna, estetyczną całość” ${ }^{12}$. Proces ten ilustruje również sfera językowa: mowa potoczna obfituje bowiem w zwroty, które opierają się na analogiach związanych ze sztuka ${ }^{13}$. Zaświadczaja o tym popularne konstrukcje językowe, jak „,kafkowska/mrożkowa sytuacja”, „czeski film”, „malowniczy widok”. Za przykład artyfikacji języka przywołać można również takie określenia jak „,surrealistyczne”, „kiczowate”, ,absurdalne” stosowane w odniesieniu do realnych (pozaartystycznych) zdarzeń. W opisie faktów spoza sztuki nawiązujemy także do podstawowych gatunków artystycznych, takich jak film (w ang. movie-situation), malarstwo (,jak z obrazka”) czy literatura (,poezja codzienności”), mówimy „życie pisze scenariusze” czy „świat to teatr”"14. Źró-

${ }^{10}$ Tamże. Warto zauważyć, że Naukkarinen, jak sam podkreśla, odnosi się w swej definicji artyfikacji do esencjonalnych ujęć sztuki, które zakładają że sztuka ma swoja „istotę”, a także jest bytem autonomicznym względem innych sfer rzeczywistości.

${ }^{11} \mathrm{~W}$ przeciwieństwie do ewolucjonistycznego ujęcia artyfikacji jako uniwersalnej ludzkiej skłonności do tworzenia sztuki (,czynienia rzeczy wyjątkowymi”), która proponuje Ellen Dissanayake. Por. E. Dissanayake, Hipoteza artyfikacji i jej znaczenie dla kognitywizmu, neuroestetyki i estetyki ewolucyjnej, „Kultura - Społeczeństwo - Edukacja” 2015, nr 2 (8).

12 Th. Leddy, dz. cyt., s. 180.

${ }^{13}$ Nawiązując do ustaleń XX-wiecznego zwrotu językowego, zakładam, że mowa (zwłaszcza potoczna) może odzwierciedlać sposób, w jaki doświadczamy świat i w związku z tym, analiza zwrotów językowych może, istotnie, dostarczać wiedzy na temat tego, w jaki sposób wchodzimy w relację z rzeczywistościa.

${ }^{14}$ Warto zauważyć, że wątki związane z toposem theatrum mundi, kojarzonym przede wszystkim z twórczością dramaturgiczną Williama Shakespeare'a (Jak wam się podoba, Makbet), odnajdujemy już w starożytnej tradycji filozoficznej. Motyw „życia jako teatru” 
dłowo, również tak powszechnie używane określenia jak „dramat”, „komedia” czy „tragedia” używane w stosunku do zdarzeń, ugruntowane są w siatce pojęć związanej ze sztuka. Jak zauważa Maria Gołaszewska w ramach rozważań zebranych pod postacią tak zwanej „estetyki rzeczywistości” („estetyki sensu largo"): ,jest na przykład wiele środków wyrazu w literaturze, które zasługiwałoby na miano struktur pojęciowych, powiedzmy - ironia. To nie tylko środek stosowany w literaturze, częsty zwłaszcza współcześnie, lecz również stosowany do rzeczywistych sytuacji. Mówimy: «ironia losu» [...]"15. Filozofka w swych strukturalistycznie zorientowanych rozważaniach analizuje bowiem taki typ doświadczenia rzeczywistości pozaartystycznej (codzienności), którego forma odpowiada strukturze doświadczenia artystycznego, a więc szczególnego rodzaju sytuację, gdy:

struktury artystyczne (kreowane w twórczości artystycznej) przenoszone są na rzeczywistość realną i okazują się stosowalne do tej rzeczywistości. Mówimy wtedy o strukturach paraartystycznych, ponieważ nie jest wówczas wytwarzany żaden przedmiot artystyczny, dzieło sztuki, lecz przedmioty zastane traktowane są na podobieństwo wytworów sztuki. [...] Struktury paraartystyczne wspólne sa sztuce i rzeczywistości - odnajdujemy je w tym co zastane - przede wszystkim dzięki sztuce $^{16}$.

Gołaszewska określa ten typ operacji myślowej mianem „estetyzacji”, co w sposób pośredni nawiązuje do utrwalonego w dyskursie estetycznym ujęcia Wolfganga Welscha czy Mike'a Featherstone'a - jak się wydaje, określenie to może zostać zaktualizowane właśnie w postaci proponowanej przez Naukkarinena, ,artyfikacji” ${ }^{17}$. Przyjąć bowiem należy, w kontekście ustaleń

znajdujemy, między innymi, u Epikteta, który w Diatrybach przyrównywał człowieka do aktora, grającego rolę w wielkim widowisku scenicznym, jakim jest życie (i polecał przy tym odgrywać tę rolę jak najpiękniej, bez względu na to, czyją postać polecono nad do zagrania żebraka czy monarchy). Myśl tę kontynuuje Marek Aureliusz w Rozmyślaniach, gdzie świat to spektakl, w którym aktorami są ludzie, a reżyserem (i jedynym widzem) - Bóg. Znamienna dla rozważań wydaje się również treść szyldu nad wejściem do teatru The Globe: „Totus mundus agit histrionem” (,Cały świat gra jakaśs rolę”), w którym nota bene wystawiał swoje sztuki Shakespeare. Co ciekawe mianem theatrum mundi (,teatr świata”) określano w XVII i XVIII wieku podręczniki do historii powszechnej. Zob. D. Kosiński, Historioni i aktorzy, „Ethos” 2007, s. 77-78.

${ }^{15}$ M. Gołaszewska, Estetyka rzeczywistości, Warszawa 1984, s. 119.

${ }_{16}$ Tamże, s. 82.

${ }_{17}$ Welsch i Featherstone łączą mechanizm estetyzacji z nowoczesnym doświadczeniem wielkiego miasta połowy XIX wieku oraz ponowoczesna, masową konsumpcja. Przy czym, dokonuje się tu również znaczącego rozróżnienia na tak zwaną estetyzację „płytką” i „głęboką. Płytka oznacza charakterystyczne dla społeczeństwa ponowoczesnego dążenie do „wszystkoładniości”, przesycanie wartością estetyczna (w sposób powierzchowny) wszystkich możliwych sfer życia, podczas gdy estetyzacja głęboka sięga samych korzeni bytu: kryteriów prawdy czy standardów moralnych. Zob. M. Featherstone, Postmodernizm i estetyzacja życia 
dokonanych na gruncie Everyday Aesthetics, że estetyzacja stanowi kategorię znacznie szerszą niż artyfikacja (która odnosi się wyłącznie do kategorii związanych ze sztuka, a nie szeroko pojęta estetycznościa). Filozofka, pisząc, że „estetyzacja rzeczywistości” ma miejsce, gdy człowiek „w szczególny sposób traktuje rzeczywistość, tak mianowicie, iż ujmuje [rzeczywistość] w struktury artystyczne" najwyraźniej, na potrzeby swej analizy, mocno zawęża znaczenie tej kategorii ${ }^{18}$.

Rozważając dzieło artystyczne w jego aspekcie mimetycznym, Gołaszewska odwraca wektory i wskazuje, że sztuka uwikłana źródłowo w świat zastany zmienia w dalszej kolejności sposoby oglądu tego świata tak, że w doświadczeniu uzyskuje on formę „sztukopodobną” (posługując się określeniem Naukkarinena). W momencie, gdy schematy poznawcze (lub ich elementy) utrwalone w dziele przenoszone są (z powrotem) na rzeczywistość zastana, świat pozaartystyczny objawia się na podobieństwo kreacji i, jak się wydaje, jest to głęboki sens powiedzenia, że sztuka jest „zwierciadłem” świata.

Artyfikacja codzienności i związane z nią przemieszanie porządków doprowadziło do sytuacji, w której zatarły się granice między dwoma podsystemami: sztuką i rzeczywistością. W tym kontekście, zmienia się również sam status gestu twórczego - szczególnie w świecie „po awangardzie” - gdyż jak zauważa Katya Mandoki:

artyzm [artifice] umożliwia prezentowanie alternatywnych wersji rzeczywistości lub ich odwracanie [di-versions] (z łacińskiego di-vertere, czyli rozlewać lub skręcać w innym kierunku). Jeżeli podejście do rzeczywistości jest bezpośrednie, nie ma odwrócenia [di-version], a jest zwykłe odwzorowanie [version], to nie mamy do czynienia ze sztuka, lecz z opisem, dokumentacja ${ }^{19}$.

Według Gérarda Genette’a „perfekcyjna imitacja nie jest już imitacja, lecz rzeczą samą w sobie” - czym, więc jest dziś dla miłośnika sztuki ready-made wieża kartonów proszku do prania ustawiona w witrynie sklepowej po Brillo Boxes Warhola?20. Jaka jest natura doświadczenia przypadkowego wieszaka na ubrania, który, ustawiony w galerii, pomylony został z dziełem sztuki? Próba odpowiedzi na to pytanie, ustalenie charakteru relacji, która

codziennego, przeł. P. Czapliński i J. Lang, [w:] Postmodernizm. Antologia przekładów, red. R. Nycz, Kraków 1997, oraz W. Welsch, Estetyka i anestetyka, przeł. M. Łukasiewicz, [w:] Postmodernizm. Antologia przekładów, red. R. Nycz, Kraków 1997.

${ }^{18}$ M. Gołaszewska, Potoczna sytuacja piękna, [w:] Estetyka codzienności, red. J. Chłopecki, A. Horbowski, Rzeszów 1988, s. 13.

${ }^{19}$ K. Mandoki, Everyday Aesthetics; Prosaics, the Play of Culture and Social Identities, Aldershot 2007, s. 270.

${ }^{20}$ G. Genette, Figures of Literary Discourse, cyt za: Th. Docherty, ANTI-MIMESIS: The Historicity of Representation, „Forum for Modern Language Studies” 1990, vol. XXVI, Is. 3, s. 273. 
zawiązuje się między dwoma płaszczyznami sztuki i nie-sztuki, próba podziału na to, co źródłowe i pochodne sprawia, że popadamy w swoisty nieskończony ciag zwierciadeł. Film naśladuje życie, a życie „naśladuje” film; kategoria „malowniczości” (picturesque) sugeruje, że obraz istniał przed rzeczywistościa; absurd autentycznego życia zdaje się przerastać fikcję (Gombrowiczowskie „zbyt głupie, by być mogło”). Twórczość awangardowa jeszcze bardziej komplikuje tę sytuację doprowadzając ją do stanu, w którym sztuka naśladuje życie... naśladujące sztukę.

\section{Odwrócony mimetyzm czyli życie, które naśladuje sztukę}

natomiast jest jedna rzecz, której - mimo że sam jestem warszawiakiem
urodzonym na Powiślu-nie rozumiem: czy Warszawa mówi tak,
jak pisze Wiech; czy też Wiech pisze tak, jak mówi Warszawa.

$[\ldots]$

Od czasu do czasu zjawiało się u mnie dwóch facetów wygląajacych jak "tapsy" z filmu. Już nigdy chyba nie dowiem się, czy ci w filmach wygladaja tak jak ci w $\dot{z} y c i u$, czy téz ci w $\dot{z} y c i u$ tak jak ci w filmach.

M. Hłasko Piękni dwudziestoletni

Awangardowe w duchu przekonanie, że świat stanowi zbiór potencjalnych dzieł sztuki (oraz przekucie tego przekonania w szereg działań o charakterze artystycznym) doprowadziło do radykalnego przeformułowania kategorii mimetyzmu i, w konsekwencji, wpłynęło również na to, w jaki sposób doświadczamy codzienność. Awangarda, utożsamiając sztukę z rzeczywistościa, sprawiła, że mimetyzm osiagnął niejako swoją pełnię, a zakres artyfikacji doświadczenia codzienności pozbawiony został wszelkich granic. Analizując proces przemieszania porządków sztuki i nie-sztuki (skutkujący przenikaniem się tych płaszczyzn aż do granicy rozpoznawalności), Rüdiger Bubner zauważa:

naprawdę nowoczesna sztuka bowiem, towarzyszaca nam od półwiecza, wcale nie chce już być antytezą rzeczywistości. Odcisnęła ślady [...] we wszechobecnych sygnałach optycznych i akustycznych, w reklamie, w żargonie. [...] tam, gdzie wąż pożarniczy należy do asamblażu, gdzie kopiec ziemi może być wypowiedzią artystyczną [...] - tam osiągamy stan, który niweluje wryte w pamięć różnice między pierwszą i drugą rzeczywistościa. [...] Efekty artystyczne przenikają także powszedniość, ona zaś wydaje się estetycznie nobilitowana ${ }^{21}$.

Twórczość przednowoczesna, ograniczona przez stosunkowo sztywne ramy dopuszczalnych form ekspresji, ograniczała tym samym zasięg me-

${ }^{21}$ R. Bubner, Doświadczenie estetyczne, przeł. K. Krzemieniowa, Warszawa 2005, s. 129.

Paula Milczarczyk 254 
chanizmów uartystyczniania świata zastanego. Jeżeli przed awangardą przedmioty czy zdarzenia pozaartystyczne musiały spełnić dyktowane przez sztukę formalne warunki, by mógł zostać zainicjowany proces artyfikacji (na przykład krajobraz naturalny zartyfikowany na wzór pejzażu malarskiego), to w świecie „po-awangardzie” wszystko może zostać poddane tej operacji. W rzeczywistości, w której podczas wernisażu czy festiwalu artystycznego nie mamy czasem pewności, co jest elementem sztuki, a co fragmentem świata zastanego, artyfikacja doświadczenia codzienności pozbawiona została granic ${ }^{22}$. Bardzo sugestywnie - w momencie, gdy ów moment przejścia osiagał stan apogeum (neoawangarda) - opisywał ten fenomen artysta i teoretyk happeningu Allan Kaprow w eseju Edukacja Nie-Artysty część I (1971):

Poziom i wyrafinowanie świadomości w sztuce dzisiaj (1969) jest tak ogromne, że ciężko już nie uznać za fakty tego, że: statek kosmiczny LM [Lunar Module] zdecydowanie prześciga wysiłki wszelkich współczesnych rzeźbiarzy; że transmitowana wymiana zdań między Centrum Lotów Kosmicznych w Houston a astronautami Apollo 11 była lepsza niż współczesna poezja; [...] że przypadkowe, transowe ruchy klientów w supermarketach są bogatsze niż cokolwiek, co powstało we współczesnym tańcu; [...] że wojna w Wietnamie lub proces mafiozów z „Chicagowskiej Ósemki”, choć moralnie nie do obrony, stanowią lepszy teatr niż jakakolwiek sztuka teatralna; [...] Nie-sztuka jest bardziej sztuką niż sztuka ${ }^{23}$.

W nawiązaniu do przytoczonego wyżej fragmentu eseju (zwłaszcza jego paradoksalnego zakończenia) przywołać można aforystyczne stwierdzenie Oscara Wilde’a (określane również jako tak zwany „paradoks Wilde’owski”) o tym, że to nie sztuka naśladuje życie, lecz życie - sztukę ${ }^{24}$. Wilde w swojej koncepcji, którą określić można mianem mimetyzmu odwróconego, zwraca uwagę na zmianę kierunku naśladowczego porządku odniesienia: bywa, że to nie świat zastany podaje sztuce wzorce, lecz odwrotnie - twórczość artystyczna sugeruje formy oglądu świata. Niekoniecznie świadomi tego pro-

${ }^{22}$ Za przykład tego typu twórczości przywołać można instalację site-specific Konrada Smoleńskiego pt. B (2014) prezentowaną premierowo podczas szóstej edycji festiwalu Narracje w Gdańsku (dwa lata później również w Zjednoczonych Emiratach Arabskich). Instalacja składa się z kilku rozlokowanych w przestrzeni miasta samochodów (nieoznaczonych jako część pracy), które „zlane” ze światem zastanym muszą zostać przez odbiorcę (niepoinformowanego o miejscu i charakterze pracy) odkryte, niejako zdemaskowane jako sztuka. Zob. http://www.konradsmolenski.com/index.php/project/2014--b/

${ }^{23}$ A. Kaprow, Essays on the Blurring of Art and Life: Expanded Edition, ed. J. Kelley, Berkeley 2003, s. 97-98.

${ }^{24}$ Jeżeli przywołamy jedną z najstarszych (sokratejsko-platońska) koncepcję mimesis, która oznacza naśladownictwo przez sztukę (wyglądów) rzeczywistości, to pomysł Wilde'a opiera się na odwróceniu tego schematu. Koncepcja pisarza określana bywa jako tzw. „anty-mimetyzm”, ale wydaje się, że sens powiedzenia o „życiu naśladującym sztukę” trafniej opisuje kategoria mimetyzmu odwróconego, ponieważ dochodzi tu jedynie do odwrócenia porządku, podczas gdy sama zasada naśladownictwa pozostaje w mocy. 
cesu formalizujemy bowiem doświadczenie według wzorców artystycznych czy sugerowanych przez kulturę popularną: „kadrujemy” widoki według wzorców malarskich (za ilustrację podać tu można, poza oczywistym przykładem twórczości pejzażowej, „malarstwo codzienności” Józefa Czapskiego czy Edwarda Hoppera), zdarzenia układamy w struktury narracyjne (opowieść jako relacja). Jako jeszcze bardziej skomplikowany przykład przywołać można przypadek, gdy świat przedstawiony w ramach dzieła (funkcjonujący na zasadzie świata pozaartystycznego, zastanego) kreowany jest na podobieństwo sztuki. Przywołać można też Pogardę (1963) Jeana-Luca Godarda, gdzie jednym $\mathrm{z}$ takich punktów odniesienia jest malarstwo abstrakcyjne (w szczególności neoplastycyzm). Budowa tego typu artystycznych quasi-rzeczywistości ma charakter szkatułkowy: świat przedstawiony zawiera $\mathrm{w}$ sobie odwołanie do innego świata przedstawionego; obraz zawiera $\mathrm{w}$ sobie obraz. Co ciekawe, nawet tak skomplikowane modele artystyczne moga z powrotem oddziaływać na doświadczenie świata zastanego. W przypadku Pogardy miałoby to miejsce, gdyby widoki poza-sztuka (sformalizowane przez kino reprezentanta francuskiej nowej fali) przywoływały skojarzenie z filmem, a więc doświadczane były jako szczególnego rodzaju „sytuacje Godardowskie". Warto w tym miejscu postawić pytanie o wartość poznawczą takiego doświadczenia. Czy ogląd świata, uwikłany w doświadczenia związane ze sztuka, ma dodatkowy wymiar, inny niż estetyczny? W tym kontekście Danto przywołuje metaforę sztuki jako zwierciadła:

Sokrates uważał, że zwierciadło odbija jedynie to, co już widzimy; stąd sztuka, jako zwierciadłopodobna, oddaje biernie i wiernie odbicie wyglądów rzeczy, nie dając żadnej korzyści poznawczej. Hamlet precyzyjniej rozpoznał wyjątkową cechę powierzchni lustrzanych, mianowicie tę, że pokazują nam one to, czego inaczej nie dostrzeglibyśmy - własną twarz i postać. Tak więc sztuka, jako zwierciadłopodobna, odsłania nas samym sobie, i mimo wszystko, nawet przy zachowaniu Sokratejskich kryteriów, jest w pewnym stopniu przydatna poznawczo ${ }^{25}$.

Z kolei Rüdiger Bubner, analizując relację między rzeczywistością a obrazem, w nawiązaniu do Platońskiej krytyki mimesis stwierdza, że obraz „nie zajmuje oszukańczo miejsca tego, co prawdziwe, jak w zwodniczej retoryce. [...] Raczej otwiera widok na to, co prawdziwe, co je uprzedza w tej mierze, w jakiej obraz się doń upodabnia" ${ }^{26}$. Za przykład podaje Bubner dramat, który „odzwierciedla «praxis» widzów”, podczas gdy „zrozumiałość fabuły [...] wynikała pierwotnie z efektu ponownego rozpoznania [«praxis»dopisek P.M.]"27. Mimesis rozumiana jest tu bowiem nie jako odtwarzanie

\footnotetext{
${ }^{25}$ A.C. Danto, dz. cyt., s. 35.

${ }^{26}$ R. Bubner, dz. cyt., s. 146.

27 Tamże, s. 147.
} 
stosunków, lecz „swobodne w swym zobrazowaniu przedstawienie czegoś, co nie jest obrazem”, w związku z czym ,sztuka mimetyczna zapewnia nam ponowne spotkanie [wyróżnienie autora] z tym, co już właściwie znamy, ale czego nie postrzegaliśmy w taki sposób"28.

Jak zauważa Gołaszewska, proces skutkujący przemieszaniem porządków sztuki i życia „dokonuje się na skutek tego, iż każdy niemal człowiek zna struktury artystyczne zaczerpnięte z literatury, filmu, teatru, telewizji. Narzucaja się najbardziej sugestywne sposoby strukturowania zdarzenia, doszukiwania się jego "głębszego sensu»" "29. Ta, szczególnego rodzaju, estetyczna asocjacja skutkuje uwikłaniem doświadczeń pozaartystycznych w zakorzenione w sztuce schematy: wizualne, dźwiękowe czy literackie. Proponowane przez siebie podejście strukturalne autorka Estetyki rzeczywistości opisuje następująco:

Jest wiele takich możliwości strukturowania dzieła sztuki, a także świata [...]. Są to struktury czasowe, przestrzenne, pojęciowe. Strukturowanie czasowe to ujmowanie zjawisk w pewien proces, mający swój początek i koniec [...]. Struktury przestrzenne górują w naszym bezpośrednim, zmysłowo danym obrazie świata, gdy dostrzegamy piękno wyglądu drugiego człowieka, piękno krajobrazu, widoku z okna czy też szybko zmieniajacego się krajobrazu z okien samochodu [...]. Struktury pojęciowe to na przykład paradoks [...]. Struktury te występują w rzeczywistości, sa jednak eksponowane i uwyraźniane w sztuce. Dzięki temu są wykrywane w rzeczywistości realnej, którą ujmujemy na podobieństwo dzieła sztuki $[\ldots]^{30}$.

Proces twórczy ma według Gołaszewskiej charakter ściśle mimetyczny: polega na odkrywaniu „naturalnych struktur rzeczywistości”, które przenoszone sa przez artystę w pole sztuki i wykorzystywane na wzór konstrukcji szkieletowej, którą wypełniana jest w dalszej kolejności materiałem. Jeżeli budowa świata zastanego determinuje postać świata kreowanego, to odkrywanie „śladów sztuki” w rzeczywistości polega na swoistym zatoczeniu koła. Doświadczenie tego rodzaju zwiąane jest bowiem z aktem przypominania, przywoływania w pamięci modeli związanych ze sztuka. W tym kontekście warto po raz kolejny przywołać ustalenia reprezentantów pokantowsko zorientowanych nurtów estetycznych, którzy zwracają uwagę na rolę, jaka w codziennym doświadczeniu odgrywa uposażenie podmiotu: wiedza, wola, wrażliwość czy właśnie - pamięć (przeszłe doświadczenia), które razem wzięte czynnie współkształtuja przedmiot poznania. „Naturalne”, „czyste” doświadczenie nie istnieje, gdyż „obciążone kulturowymi założeniami i oczekiwaniami, uwarunkowane edukacją i cała resztą procesu socjalizacji,

${ }^{28}$ Tamże, s. 147-148.

${ }^{29}$ M. Gołaszewska, Estetyka rzeczywistości..., s. 184.

${ }^{30}$ Taż, Estetyka o orientacji empirycznej, [w:] Estetyki filozoficzne XX wieku, red. K. Wilkoszewska, Kraków 2000, s. 323-324. 
kierowane przyzwyczajeniami [...] - zostaje przefiltrowane przez nasze struktury kognitywne, by wyłonić się w mniej lub bardziej ukształtowanej formie" - podkreśla jeden z głównych przedstawicieli estetyki codzienności, Arnold Berleant ${ }^{31}$.

\section{Zakończenie}

Ulice Nowego Orleanu maja dtugie, melancholijne perspektywy; w pustych godzinach ich atmosfera przypomina Chirico, a rzeczy zazwyczaj niewinne [...] nabieraja cech groźnych

T. Capote Koloryt lokalny

Sztuka awangardowa, zawłaszczając i wchłaniając w swoje pole elementy rzeczywistości pozaartystycznej, dopełniła proces postępującej dominacji potocznego doświadczenia przez modele artystyczne. Artyfikacja świata zastanego - doświadczenie życia na wzór dzieła sztuki - skutkuje jednak nie tylko poszerzeniem pola występowania codziennych przeżyć estetycznych, lecz ma również konsekwencje sięgające sfery moralnej. Karlheinz Stockhausen, określając ataki terrorystyczne z 11 września „największym dziełem sztuki, jakie kiedykolwiek powstało, [...] największym dziełem sztuki w całym wszechświecie", poddał ów zbrodniczy akt właśnie procesowi artyfikacji, a w związku z tym jednocześnie - i jak się wydaje mimowolnie - przeniósł zbrodnię w sferę wartości, z którą łączymy sztukęe $e^{32}$ Sam Arthur C. Danto, choć pozytywnie ustosunkowany do czytania elementów świata zastanego poprzez sztukę, zaznacza swój krytyczny stosunek wobec uartystyczniania tragicznych wydarzeń, piszac: „uważam zreszta, że w pewnych sytuacjach zajęcie postawy estetycznej, psychiczne zdystansowanie się do pewnych wydarzeń, byłoby błędne lub nieludzkie, na przykład traktowanie zamieszek, w których policja używa pałek wobec demonstrantów, jako rodzaju baletu"33. Jak się wydaje, artyfikacja w tej

${ }^{31}$ A. Berleant, Prze-myśleć estetykę. Niepokorne eseje o estetyce $i$ sztuce, przeł. M. Korusiewicz, T. Markiewka, Kraków 2007, s. IX (przedmowa).

${ }^{32}$ Cyt. za: A. Berleant, Wrażliwość i zmysty, przeł. S. Stankiewicz, Kraków 2011, s. 195. Po fali krytyki, która narosła wokół tej wypowiedzi, kompozytor bronił się, sugerując, że został źle zrozumiany przez dziennikarza przeprowadzającego wywiad - dopowiadając jednocześnie, że miał na myśli „szatańskie dzieło sztuki”. Określenie użyte w sprostowaniu, choć potępiające, wciąż jednak opiera się na zartyfikowaniu omawianych zdarzeń. Zob. obszerne studium przypadku: R. Schechner, 9/11 as Avant-Garde Art?, „PMLA” 2009, vol. 124, no 5 oraz A. Berleant, Wrażliwość..., rozdział pt. „Negatywna estetyka codzienności” oraz „Sztuka, terroryzm i wzniosłość negatywna".

${ }^{33}$ A.C. Danto, dz. cyt., s. 64. 
postaci skutkuje wytworzeniem specyficznego dystansu wobec wydarzeń, odrealnieniem ich, wzięciem w „ontologiczny nawias”. Krytyczny stosunek do przemieszania porządków sztuki i życia, choć już z innej pozycji, reprezentuje również Odo Marquad, który estetyzację opisuje jako proces skutkujący właśnie odrealnieniem rzeczywistości, gdy: „[...] sztuka spod znaku estetyki - zapominając o granicach sztuki - wciaga całą rzeczywistość w majak i trans sztuki i niejako rzeczywistość zastępuje sztuką", sprawiając tym samym, że rzeczywistość staje się tak zwaną fiktura, bytem bardziej fikcyjnym niż sztuka ${ }^{34}$. Według Marquarda nowoczesna rzeczywistość, która coraz bardziej staje się fiktura (Baudrillardowskim symulakrem), „wymusza” na sztuce zwrot ku realności. Sztuka na mocy swej fikcjonalnej definicji staje się $\mathrm{w}$ takiej sytuacji wymienialna z rzeczywistością pozaartystyczna, dlatego też - by zachować swą niezastępowalność - staje się antyfikcja, rzeczywistością zradykalizowana ${ }^{35}$. „Nie tylko sztuka staje się życiem, ale życie odmawia bycia sobą" - zauważa Alan Kaprow, dopowiadając jednocześnie, że „wszelkie rozróżnienia na sztukę, anty-sztukę, czy nie-sztukę sa już tylko pseudo-rozróżnieniami” ${ }^{36}$.

Model postrzegania świata zastanego w odniesieniu do sztuki określić można mianem mimetyzmu odwróconego: gdy element inspirowany światem - przetransponowany w dzieło sztuki - wraca w formie schematu poznawczego, który (z powrotem) wpływa na ogląd świata zastanego. Zartyfikowanie doświadczenia codzienności, które zilustrować można pojęciem „Turnerowskiego krajobrazu” skutkuje poszerzeniem pola potencjalnych przeżyć o charakterze estetycznym, lecz uwikłane jest również w sferę moralności. Odwrócenie porządków, którego konsekwencją jest efekt „życia naśladującego sztukę" związane jest bowiem z procesem przenikania się, aż do granicy rozpoznawalności, dwóch płaszczyzn: sztuki i życia. Zauważa to R. Bubner, pisząc „Mimesis jest czymś pierwszym [wyróżnienia autora], nie wtórnym, ponieważ z rzeczywistością wolną od mimesis, z rzeczywistością samą w sobie, która nie obawiałaby się nadwątlenia przez obrazy, spotykamy się coraz rzadziej" ${ }^{37}$. Wykorzystując słynną metaforę Paula de Mana (opisująca relację między fikcją i rzeczywistością w autobiografii), artyfikację można więc określić jako wejście w nieustannie kręcące się „drzwi obrotowe" między sztuką a życiem, z których to drzwi, jak się wydaje, nie sposób się już wydostać.

${ }^{34}$ O. Marquard, Aesthetica $i$ anaesthetica. Rozważania filozoficzne, przeł. K. Krzemieniowa, Warszawa 2007, s. 8.

${ }^{35}$ Zob. tamże, Sztuka jako antyfikcja. Rzeczywistość $w$ drodze ku fikcji, s. 155-185.

${ }^{36}$ A. Kaprow, dz. cyt., s. 81.

${ }^{37}$ R. Bubner, dz. cyt., s. 164. 


\section{BIBLIOGRAFIA}

Berleant A., Prze-myśleć estetykę. Niepokorne eseje o estetyce i sztuce, przeł. M. Korusiewicz, T. Markiewka, Kraków 2007.

Berleant A., Wrażliwość i zmysty, przeł. S. Stankiewicz, red. K. Wilkoszewska, Kraków 2011.

Bubner R., Doświadczenie estetyczne, przeł. K. Krzemieniowa, Warszawa 2005.

Capote T., Psy szczekaja, przeł. B. Zieliński, Warszawa 1982.

Danto A.C., Świat sztuki. Pisma z filozofii sztuki, przeł. L. Sosnowski, Kraków 2006.

Dissanayake E., Hipoteza artyfikacji $i$ jej znaczenie dla kognitywizmu, neuroestetyki i estetyki ewolucyjnej, „Kultura - Społeczeństwo - Edukacja” 2015, nr 2 (8).

Docherty T., ANTI-MIMESIS: The Historicity of Representation, „Forum for Modern Language Studies" 1990, vol. XXVI, is. 3, s. 272-281.

Eco U., Semiologia życia codziennego, przeł. P. Salwa, J. Ugniewska, Warszawa 1996.

Featherstone M., Postmodernizm i estetyzacja życia codziennego, przeł. P. Czapliński, J. Lang, [w:] Postmodernizm. Antologia przekładów, red. R. Nycz, Kraków1997.

Gołaszewska M., Estetyka o orientacji empirycznej, [w:] Estetyki filozoficzne XX wieku, red. K. Wilkoszewska, Kraków 2000.

Gołaszewska M., Estetyka rzeczywistości, Warszawa 1984.

Gołaszewska M., Potoczna sytuacja piękna, [w:] Estetyka codzienności, red. J. Chłopecki, A. Horbowski, Rzeszów 1988.

Hłasko M., Piękni dwudziestoletni, Warszawa 1995.

Kaprow A., Essays on the Blurring of Art and Life: Expanded Edition, ed. J. Kelley, Berkeley 2003.

Kosiński D., Historioni i aktorzy, „Ethos” 2007, 77-78, s. 135-146.

Leddy T., The Extraordinary in the Ordinary: The Aesthetics of Everyday Life, Peterborough 2012.

Mandoki K., Everyday Aesthetics; Prosaics, the Play of Culture and Social Identities, Aldershot 2007.

Marquard O., Aesthetica i anaesthetica. Rozważania filozoficzne, przeł. K. Krzemieniowa, Warszawa 2007.

Naukkarinen O., Variations in Artification, „Contemporary Aesthetics”, Special Issue $2012,4$.

Pękala T., Awangarda i ariergarda. Filozofia sztuki nowoczesnej, Lublin 2000.

Saito Y., Everyday Aesthetics, New York 2007.

Welsch W., Estetyka i anestetyka, przeł. M. Łukasiewicz, [w:] Postmodernizm. Antologia przekładów, red. R. Nycz, Kraków 1997. 